\title{
The impact of nutrition on the health of the elderly
}

\author{
Despotovic M Milena ${ }^{1}$, \\ Despotovic Mile ${ }^{2}$ \\ Ilic Biljana ${ }^{2}$, \\ Stanojevic Cedomirka², \\ Stanojevic Vojislav ${ }^{3}$, \\ Urosevic Jadranka ${ }^{2}$
${ }^{1}$ Faculty of Medical Sciences, Univesity of
Kragujevac
2 Medical College, Cuprija
${ }^{3}$ General Practice Health Center Zajecar, Serbia \\ Received: $3^{\text {rd }}$ October 2016 \\ Corresponding author: \\ MirelaNedelescu, \\ National Institute of Public Health, \\ Dr. Leonte Street, no. 1-3, Bucharest, Romania. \\ E-mail: mirela.nedelescu@insp.gov.ro
}

\begin{abstract}
Introduction: Elders have higher health risks due to changes connected with general abilities and everyday functioning as a result of biological ageing. Researchers have shown that 4 out of 5 elderly people suffer from some kind of chronic illness, and the needs of this population are mainly connected to the supply of adequate medical and social support. Adequate nutrition is an important protection factor, characteristic for the general health of the elderly population, in cases such as chronic cardiovascular diseases, cognitive problems, etc. Both obesity and malnutrition are important health problems amongst elders. The aim: The aim of this article is to analyze the importance of effects related to the nutritional needs amongst the elderly and to provide guidance for further researches. Materials and methods: The article is written based on recent scientific literature review, and uses descriptive methods and scientific documents analysis. Nutrition and health of elderly: Persons above the age of 65, suffer higher risk of health problems due to nutritional factors associated with illnesses commonly related to ageing, such as co morbidity in correlation with psychological health. Luger and others found connections between malnutrition, social participation and Qol amongst elders. Despite that, they couldn't prove if malnutrition is cause or consequence. New studies have shown nutrition has important influence on skeletomuscular pain, liver diseases, fractures, cardiovascular diseases, diabetes, cognitive problems and colorectal cancer. Conclusion: Based on present knowledge, we can conclude that adequate nutritional supply can work as an important protective factor to benefit the general health status of the elders. It is necessary to develop national health strategies, educate population, while national Social and Health policies needs to recognize the nutritional needs of elderly people to ensure they are able to get the right amount of healthy foods required for securing their well being. New research should focus on different dietary styles and gender differences in health status connected to dietary intake.
\end{abstract}

Keywords: nutrition, elders, health

\section{INTRODUCTION}

Elderly population often faces increased health risks that arise due to the changes related to their abilities and daily functioning, caused by biological ageing of the body. Some studies have shown that four out of five elderly people suffer from a chronic disease and, most commonly, the needs of the older population are related to medical and social support [1]. According to the World Health Organization, there are about 605 million of elderly people in the world, of which about 400 million live in poor countries. It is believed that by 2025 , the number of elderly people in poor countries will exceed 840 million. Based on data available from the World Health Organization, the percentage of elderly people in the global population increases from year to year, which especially contributes to the importance of developing specific strategies for improving the health of the elderly, with an emphasis on prevention of diseases characteristic of this age [2]. Nutrition and nutritional status have very important role in maintaining good health, functioning independence and body resistance. Diseases such as anemia, malnutrition, obesity, constipation, etc., are related to dietary habits and nutrition. Recommended type of diet can decrease the risk of nutrition related diseases, but on the other hand, unhealthy dietary habits can be the reason of chronic diseases that can lead to rapid and pathological ageing [3]. The research conducted by Giuli et al. in Italy, was aimed to determine the correlation of the quality of life, health related, in obese, overweight, and normal weight adult patients in Italy. The results showed lower levels of life satisfaction and poorer health in obese and those whom were overweight, compared to normal weight patients $[4,5]$.

One of the major problems is that the bad nutritional habits of elderly often remain unrecognized and unidentified on time. It happens often that older people are being sent to counseling or advised to make changes to their regular diet only when they see a doctor because 
of the newly created health issue. Unfortunately, most of the professionals and responsible institutions do not identify the problem of inadequate nutrition of old people during the routine examinations.

Particular attention should be paid to the promotion of a healthy diet for the elderly in poor countries, taking into account that many of the essential ingredients are unavailable to them. As examples of good preventive health care policies, these are often the countries of Northern Europe, especially Finland [6]. However, poor countries are often devastated by a number of issues that directly affect the health profile of the population. Due to the lack of resources, as well as educators, most countries are reluctant to initiate this process.

\section{THE AIM}

The aim of this paper is to discuss the impact of nutrition on the health status of the elderly, taking into account the existing literature, and on the basis of the analysis of existing knowledge provide recommendations for further research in this field.

\section{MATERIALS AND METHODS}

The paper gives an overview of the existing scientific literature and uses techniques of descriptive method and analysis of documentation.

\section{NUTRITION AND HEALTH OF ELDERLY PEOPLE}

Nutrition causes musculoskeletal pain, liver disease, fractures, as well as cardiovascular diseases, diabetes, cognitive abilities, oral health, but also to the prognosis of the outcome of colorectal cancer. Malnutrition and weight loss have serious consequences for the health of the elderly. The use of nutritional supplements can provide functional benefits in this population. Inadequate calorie intake is a factor which is consistently associated with weight loss and the use of supplements in nutrition can increase the weight of elderly people with acute and chronic illnesses. These supplements do not improve functionality and do not affect mortality in the general population of aged people but show good results in those who are weak or malnourished [7].

It was found that people older than 65 are exposed to greater nutritional risks due to greater exposure of comorbid diseases due to psychological factors caused by ageing [8]. The study by Luger and others showed that there is a significant correlation between malnutrition, lower quality of life and social participation. However, this research has not established the exact direction of causes and effects. A significant correlation was found between nutritional status and quality of life for elderly people in collective flats (community apartments) in Vienna, especially for the domains "autonomy" and "participation in society". However, it remains unclear whether the nutritional status is a cause or a consequence, or it is the intermediation of the potential third factor that has influenced the result [9].

Effects of nutrition among poor elderly people with hip fractures have rarely been investigated. Secondary analysis of data from randomized trial with 24 months follow-up conducted in Taiwan, tries to answer this question. The original study was conducted in a large medical center in northern Taiwan, with about 3000 beds. Only the respondents who had "poor nutrition" on the discharge from the hospital were considered, including those at risk of malnutrition. Data were collected relying on nutritional status and physical functions, including range of motion, muscular strength, balance and functional independence, and were analyzed using the approach of generalized estimation of equations. Besides, the main characteristics of patients were discussed: demographic characteristics, type of surgery, comorbidity, length of hospitalization, cognitive functions and depression. The results have shown that patients with poor nutrition who got comprehensive care have 1.67 greater chances to improve their nutritional status compared to those who received an interdisciplinary and usual care [10].

Osteoporosis is a health problem that has multiple effects on the lives of elderly people, especially in the context of injuries and fractures. Injuries caused by osteoporosis result in new inabilities and are the reason of taking patients in hospitals, nursing homes and long-term care facilities. Besides, the treatment of these injuries costs billions of dollars on a national level. Healthy choices and lifestyle including the therapy on the basis of vitamins and minerals, a stable environment; diet full of calcium, vitamin $\mathrm{D}$ and proteins; support and resistance exercises, as well as the promotion of prevention programs contribute reducing the number of injuries caused by osteoporosis [11]. Special attention is paid to the impact of nutrition in the treatment of osteoporosis and the effects of nutrition on the prevention of injuries.

The effects of vitamin $D$ in the diet of elderly were further investigated in order to define its protective character in preserving bone density and preventing injuries and fractures. The effects of vitamin $D$ doses larger than recommended on the density and quality of bone are not known sufficiently. Existing studies examined how a bone responds to the standard dose of vitamin $D$, but the results are often contradictory and unclear. In addition, the effects of higher doses on the density and quality of the bone have not been examined. Postmenopausal women undergo changes in the body weight and changes in hormonal status expose them to a particular risk of losing bone mass, so that they can benefit from taking vitamin $D$ above the recommended value. One-year, randomized, double-blind controlled study examined the influence of vitamin $D$ in healthy obese older women on the density and quality of bone in fifty eight elderly women surveyed. The decline in the thickness of the cortical width of the tibia was prevented by 
the treatment of higher doses of vitamin $D$, but there were no other significant changes caused by the treatment over a period of one year [12].

Reduced capacity and limited functioning greatly complicate the life of elderly, so that eating habits of this population must be such as to respond to the needs of the body. It is necessary to ensure a good correlation of all necessary nutrients. It is especially important that older people bring plenty of fluids in the body to prevent dehydration of the body. The loss of water or dehydration of the body in the elderly is associated with increased mortality and disability. The aim of the research conducted in the UK is to assess the incidence of dehydration in elderly people who live in this country as well as the long-term care and related cognitive, functional and health characteristics. It was found that dehydration was present in $20 \%$ of 188 patients, average age 86 years. Linear and logistic regression analyses have shown that the kidney, cognitive and diabetes status are consistently correlated with the risk of dehydration, while the diuretics on the basis of potassium, gender, number of recent healthcare contacts, and urinary incontinence are sometimes associated with the dehydration. The thirst had no impact on the results. The conclusion was that dehydration is often present in older people living in the UK and that it is necessary to further investigate the relationship between cognitive and kidney functions and hydration of the body [13].

Musculoskeletal pain is defined as the presence of pain in the last six months, which has not disappeared for at least 30 consecutive days. Nutrition habits have been associated with the chronic musculoskeletal pain. Individuals classified into a category of medium or high nutritional risk had significantly higher chances ( 90\%) of musculoskeletal pain compared to those who were in the low risk category [14].

Evident is the impact of dietary habits on the occurrence of liver disease in the elderly. Excessive weight, defined by a body mass index and percentage of body fat, has been associated with the condition of fatty liver in the elderly [15].

The study conducted on the island of Menorca has shown that five percent of older participants were malnourished, while $60 \%$ of people were overweight or obese. The prevalence of obesity was $66.8 \%$ in male and $85.1 \%$ in female population. Same study has found that BMI correlates with parameters such as hypertension, hypercholesterolemia, heart insufficiency and other cardiovascular diseases[16].

Poor dietary habits often lead to the development of hypertension in the elderly. Excessive consumption of coffee, low levels of potassium and magnesium, as well as high levels of sodium, are just some of the problems related to inadequate nutrition. Numerous studies have shown that coffee raises blood pressure by 5-15 $\mathrm{mmHg}$ and maintain it at that level for the next two hours. [17]

Some studies have proven the correlation between diet and cognitive abilities in the elderly. It is evident that there is a relationship between metabolic syndrome and cognitive abilities and functions in the elderly [18]. Alzheimer's disease is mainly characterized by the accumulation and aggregation of amyloid-b (Ab) peptides in the brain parenchyma and cerebral microvasculature. Unfortunately, the exact causes of the disease are still unclear. However, the dysfunctional blood-brain barrier and activation of inflammatory pathways are involved in the $A D$ pathogenesis. The influence of a diet rich in fats on the development of Alzheimer's disease was examined using animal model. The results have shown that such a diet accelerates the cognitive reduction in this disease [19].

The impact of nutrition on oral health of the elderly is well known. The aim of a Spanish study was to determine the relationship between oral health of life quality in relation with oral health and risk of malnutrition in the elderly. This study shows that poor eating habits were 3.43 times more frequent in patients with poorer oral health. The correlation was determined between nutrition and inadequate dietary habits and lower quality of life related to oral health [20].

Finally, it should be noted that proper nutrition can have an effect on the prevention of malignant diseases in the elderly. A study by Kaneko, Sasaki et al, demonstrated that malnutrition was put into a significant relationship with the outcomes of colorectal cancer. The survey included the elderly ill people. It was evident that malnutrition correlates with lower survival rate [21]. It is believed that about $80 \%$ of malignant diseases can be influenced through the modification of risk factors. Inadequate nutrition is one of the most important risk factors, thus, it is necessary to point out that the promotion of proper nutrition has extraordinary public health significance [22].

Previous studies have determined a positive impact of the optimal nutrition on health status of the elderly. Meals should contain a sufficient amount of dietary fiber, then, iron, folic acid, calcium and vitamin D. At the same time, the amount of water must ensure the proper functioning of the body and prevent dehydration while intake of salt should be reduced [23].

Many conditions characteristic of old age, such as chronic non-infectious diseases or cognitive problems can be inhibited or prevented by proper nutrition, and the future of treating these diseases lies in the proper eating habits.

\section{CONCLUSION}

Based on current data, we can make a conclusion that nutrition habits function as a protective factor when it comes to the health status of the elderly. In order to meet the health needs of this population, it is essential to develop new national strategies, educate population and, through health and social policies, ensure the elderly access to the healthy and nutritious foods. Future studies should focus on the impact of different nutrition styles, and an additional explanation of different impacts of nutrition on the health of different genders or segments of the elderly population. At the same time, it is necessary to work on education and training 
of population, especially people older than 65 . There is a need for harmonization of international trends and national health systems in order to provide better health of the elderly, prolongation of life expectancy and the promotion of active aging.

\section{REFERENCES}

1. Sataric N, Rasevic M. Non-institutional Protection of the Elderly in Serbia - gap between needs and possibilities, Belgrade: Amity, 2007.

2. WHO, Nutrition for older people, available et: http://www.who.int/nutrition/topics/ageing/ en/index1.html

3. Urošević J. Prevention of handicap situation of elderly people through active ageing support. Ph.D. Thesis. Belgrade. University of Belgrade, Faculty of education and special rehabilitation; 2016.

4. Giuli C, Papa R, Bevilacqua R, Felici E, Gargrialdi C, Marcellini F, et al. Correlates of perceived health related quality of life in obese, overweight and normal weight older adults: an observational study. BMC Pub Health. 2014, Vol. 14 Issue 1, p1-17.

5. Despotovic M. Social support as a determinant of quality of life of elderly in rural area of Jagodina. Master Thesis. Medical Faculty, University of Belgrade. 2015.

6. Pietinen $P$, Männistö $S$, Valsta LM, SarlioLähteenkorva S. Nutrition policy in Finland. Public Health Nutr. 2010 Jun;13(6A):901-6.

7. Gammack JK, Sanford AM. Caloric supplements for the elderly. Curr Opin Clin Nutr Metab Care. 2015 Jan; 18(1):32-6.

8. Wells J, Dumbrell A. Nutrition and Aging: Assessment and Treatment of Compromised Nutritional Status in Frail Elderly Patients.Clin Interv Aging. 2006 Mar; 1(1): 67-79.

9. Luger E, Haider S, Kapan A, Schindler K, Lackinger C, Dorner TE. Association between Nutritional Status and Quality of Life in (Pre) frail Community-dwelling Older Persons. ] Frailty Aging. 2016;5(3):141-8

10. Liu HY, Tseng MY, Li HJ, et all. Comprehensive care improves physical recovery of hipfractured elderly Taiwanese patients with poor nutritional status. J Am Med Dir Assoc. 2014 Jun;15(6):416-22.

11. Parsons LC. Osteoporosis: incidence, prevention, and treatment of the silent killer. Nurs Clin North Am. 2005 Mar;40(1):119-33.

12. Pop LC, Sukumar D, Schneider SH, et all. Three doses of vitamin $D$, bone mineral density, and geometry in older women during modest weight control in a 1-year randomized controlled trial. Osteoporos Int. 2016 Aug 17. Epub ahead of print

13. Hooper L, Bunn DK, Downing A, at all. Which Frail Older People Are Dehydrated? The UK DRIE Study. J Gerontol A Biol Sci Med Sci. 2015 Nov 9. pii: glv205.

14. Pereira Costa B, Carneiro Machado A, Domingues Dias $M$, et all. Nutritional Risk is Associated with Chronic Musculoskeletal Pain in Community-dwelling Older Persons: The PAINEL Study. J Nutr Gerontol Geriatr. 2016;35(1):43-51.

15. de Melo Portela $C L$, de Carvalho Sampaio HA, Pereira de Melo ML, et all. Nutritional status, diet and non-alcoholic fatty liver disease in elders. Nutr Hosp. 2015 Nov 1;32(5):2038-45.

16. Ferra A, Bibiloni Mdel M, Zapata ME, at all. Body mass index, life-style, and healthy status in free living elderly people in Menorca Island. J Nutr Health Aging. 2012 Apr;16(4):298-305.

17. Despotovic M. Social support as a factor of health and quality of life of elderly people with hypertension. Ph.D.Thesis. Kragujevac: University of Kragujevac, Faculty od medical sciences; 2014.

18. Raffaitin C, Féart C, Le Goff M, et all. Metabolic syndrome and cognitive decline in French elders: the Three-City Study. Neurology. 2011 Feb $8 ; 76(6): 518-25$.

19. Thériault $P$, EIAli $A$, Rivest $S$. High fat diet exacerbates Alzheimer's disease-related pathology in APPswe/PS1 mice. Oncotarget. 2016 Sep 21. doi: 10.18632/oncotarget. 12179. [Epub ahead of print]

20. Jiménez-Redondo $S$, Beltrán de Miguel $B$, Gómez-Pavón J, et all. Food consumption and risk of malnutrition in community-dwelling very old Spanish adults ( $\geq 80$ years). Nutr Hosp. 2016 Jun 30;33(3):263.

21. Kaneko M, Sasaki S, et all. Underweight status predicts a poor prognosis in elderly patients with colorectal cancer. Mol Clin Oncol. 2016 Sep;5(3):289-294.

22. Stanojevic C, Stanojevic $V$, Despotovic M, Despotovic M, Vukosavljevic-Sebez I. Problems in the implementation of the national programme of organiyed screening of malignant diseases. Med Cas (Krag) / Med J (Krag) 2015; 49(4): 122-129.

23. Nutrition of elderly. Institute of public Health of Vojvodina. Available at: http://www.izjzv.org. rs/uploads/8baa2c98c0028a954c57b5ef71d6e 3d4/ishrana_starih_osoba.pdf 


\section{Uticaj ishrane na zdravlje starih}

Despotovic M Milena ${ }^{1}$, Despotovic Mile2,

Ilic Biljana²,

Stanojevic 'Cedomirka²,

Stanojevic Vojislav ${ }^{3}$,

Urosevic Jadranka²

\section{Kratak sadržaj:}

Uvod: Starije osobe se često suočavaju sa povećanim zdravstvenim rizicima koji nastaju usled promena vezanih za sposobnosti i svakodnevno funkcionisanje, prouzrokovanih biološkim starenjem organizma. Neka istraživanja su pokazala da četvoro od petoro starih Ijudi boluje od nekog hroničnog oboljenja i da su najčešće potrebe starog stanovništva vezane za medicinsku i socijalnu potporu. Pravilna ishrana se smatra protektivnim faktorom kod brojnih stanja karakterističnih za starije životno doba, uključujući hronična kardiovaskularna oboljenja, ali i kognitivne probleme. I gojaznost $i$ neuhranjenost predstavljaju probleme vezane za nepravilnu ishranu starih. Cilj rada: Cilj ovog rada je da uvidom u postojeću literaturu razmotriti uticaj ishrane na zdravstveni status starijih osoba $i$ na osnovu analize postojećih saznanja da predloge za naredna istraživanja na ovom polju. Materijal i metode: Rad daje pregled postojeće naučne literature i koristi tehnike desktiptivne metode $i$ analize dokumentacije. Ishrana i zdravlje starih: Utvrđeno je da su osobe starije od 65 godina izložene većim nutritivnim rizicima usled većoj izloženosti komorbidnih bolesti nastalih delovanjem psiholoških faktora izazvanih starenjem. Istraživanje Lugera i saradnika pokazalo je da postoji značajna veza između neuhranjenosti, niže ocene kvaliteta života i socijalne participacije. Ipak, ovo istaživanje nije ustanovilo tačan smer uzroka i posledica. Novije studije pokazale su da ishrana utiče na pojavu skeletomuskularnog bola, bolesti jetre, prelome, kao i kardiovaskularne bolesti, dijabetes, kognitivne sposobnosti, kao i na prognozu ishoda kolorektalnog kancera. Zaključak: Na osnovu postojećih podataka, može se zaključiti da način ishrane deluje kao protektivni faktor kada je u pitanju zdravstveni status starijih osoba. U cilju zadovoljenja zdravstvenih potreba ove populacije, neophodno je razviti nove nacionalne strategije, edukovati stanovništvo, a zdravstvenom i socijalnom politikom obezbediti starima pristup zdravim i hranljivim namirnicama. Buduća istraživanja treba da se fokusiraju na uticaj različitih stilova ishrane $i$ dodatno objašnjenje različitog uticaja ishrane na zdravlje starih različitih polova.

Ključne reči: ishrana, stari, zdravlje. 